As one Sault College student remarked, "I believe this is advice that all the first-year students need at this point." Another student pointed out that Peter's message, "be technology literate-spatial GIS skills very impor- tant," helped him truly appreciate the importance of the GIS course he was taking.

Section Chair Lesley Phillips congratulated organizers and thanked speakers and participants for a job well done. Total participation topped 50, with an even balance in each location and a total of 29 students.

The COS has a solid track record for its annual Winter $\mathrm{KE}$ and is already talking about ideas for the 2016 event.

\title{
Former CEO Recognized as Forest Sector Champion
}

$F^{\mathrm{p}}$

PInnovations' Provincial Leader for Ontario, John Pineau, was named a recipient of the Ontario Forest Industry Association's - Forest Sector Champion Award. These awards are given to those whose leadership has ensured Ontario's forest sector continues to employ over 150,000 Ontarians in over 260 communities. The award was presented February $25^{\text {th }}$ at the Ontario Forest Industries Association's 72nd annual meeting in Toronto.

The Forest Sector Champion Award recognizes John's dedication, strong leadership and contribution to Ontario's forest industry, especially during his eight-year tenure with the Canadian Institute of Forestry/Institut forestier du Canada (CIF/IFC). Prior to joining FPInnovations in 2014, he served as the CIF/IFC's Chief Executive Officer, where he worked tirelessly to help lead the organization to modernize and increase its public outreach and communications capacity, promoting effective knowledge exchange and a better understanding of forestry practices everywhere. John also helped to initiate and grow the CIF/IFC's continuing education and professional development value through new and innovative products and services. A trained biologist and geographic information systems technician, John has also worked for the Ontario Ministry of Natural Resources and Forestry and for various companies in numerous capacities in the forest sector across Canada.

He currently serves on the Board of Directors of the Canadian Ecology Centre and the Canadian Ecology Centre Foundation, the Friends of the Petawawa Research Forest, and was

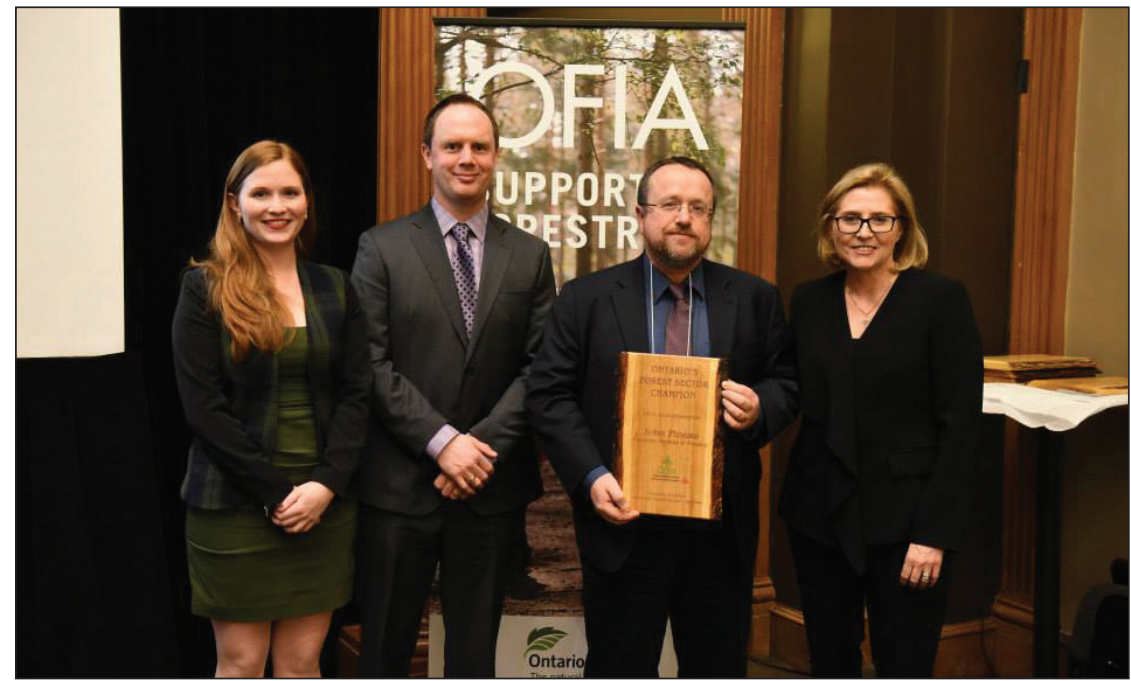

Ontario Forest Industries Association (OFIA] presents Forest Sector Champion Award to John Pineau. Left to right - Christine Leduc, OFIA Director of Policy and Communications, Kris Heidemen, OFIA Board Chair, John Pineau of FPInnovations, and Jamie Lim, OFIA President and CEO.

recently appointed by the Premier of Ontario to the Board of the Algonquin Forestry Authority.

"We congratulate John and we are very proud that our Provincial Leader for Ontario has been named a forest sector champion," said Pierre Lapointe, President and CEO of FPInnovations. "FPInnovations has always been dedicated to deliver our commitment to help Ontario's forest products manufacturers develop new value-added wood products and solutions using the innovative know-how of FPInnovations, creating jobs and providing economic benefits to the communities in which they are located."

FPInnovations is a not-for-profit world-leading $\mathrm{R} \& \mathrm{D}$ institute that spe- cializes in the creation of scientific solutions in support of the Canadian forest sector's global competitiveness and responds to the priority needs of its industry members and government partners. It is ideally positioned to perform research, innovate, and deliver state-of-the-art solutions for every area of the sector's value chain, from forest operations to consumer and industrial products. FPInnovations' staff numbers more than 525. Its research and development laboratories are located in Québec City, Montréal and Vancouver, and it has technology transfer offices across Canada. For more information about FPInnovations, visit: www.fpinnovations.ca. 